\title{
PROFESSOR ROSE AND ZURICH FEMALE S'IUDEN'TS.
}

DÉar Sir, - In answer to the questions in your letter, I must state that Miss Smith, of America, has been my sub-assistant during the past summer (1879), and that the story told in the published letter (in the Boston Daily Advertiser) is passably correct.

We have always female students, but those from Russia have nearly all disappeared since the well-known ukase, much to our satisfaction; as their number was very large we do not consider it a misfortune.

The communication in the Koelnische Zeitung is based probably on the fact that at first only very earnest and industrious ladies entered, but later many coquettish and hysterical ones, who have caused a strong prejudice against the whole question. At present the female students, and especially Miss Smith, are again much more industrious and earnest in their studies, - quite as much so as are the male students. After all that has happened they are allowed to continue here, and, as expected, after twelve years' trial, they do not cause any great excitement. Two of our female students, having passed the examinations here, practice in Zurich, two others in Berlin, one in London, one in St. Petersburg, etc., all with success.

The Russian ladies were doubtless intimately connected with the nihilists, and the action of the Russian government is therefore easily understood. The number of students of the uuiversity here has grown very large, because every foreigner formerly was admitted without any examination. The fact that, for instance, several mistresses of German noblemen tried to be admitted induced the government, in accordance with a proposition made by the senate, to pass an order making a testimonium morum requisite for the admission of a lady student, and also the proof of a certain standard of education. We are, therefore, now able to prevent similar occurrences: There have been no disturbances between male and female students, but several marriages (two or three). The official papers which I send will enable you to understand better the state of the question.

ZURICH, August 17, 1879.

Yours truly, EDMund Rose.

\section{SHORT COMMUNICATIONS.}

\section{PSEUDO-HYPERTROPHIC PARALYSIS.}

BY s. G. WEBbER, M. D.

IN the number for September 11 th "Enquirer" asks, "What is the pathology of the above-named disease?"

In the Journal for November 17, 1870, I gave, in tabular form, a summary of all the cases of which I could at that time find record, numbering forty-one. I have now the references to thirty-five or forty authors who have since that date reported from one to four or five cases each, a total of about one hundred and fifty cases. I have also since then seen three undoubted cases of the disease : two were sisters, and one case in which there might be a doubt as to the diagnosis.

Almost without exception the disease begins in early life, before eight years of age, generally as early as three, sometimes before the second year. First there is weakness; then

1 Written to a friend in this city. 
the calves increase in size, sometimes the peronei and tibial muscles; occasionally a few of the muscles moving the thigh on the pelvis or those of the shoulder are enlarged. As the child grows older certain muscles, especially those of the upper extremities, are affected with atrophy. There are pauses in the progress of the disease, but a cure is not to be expected. In a few cases a fall has preceded the development of the symptoms, or there has been an acute febrile attack, such as measles, but in most cases there is no history of a previous injury or disease. It might be questioned whether these accidents have really been the canse of the affections.

The disease is of long duration; the patients see many physicians, at last are given up as hopeless cases, and die of some intercurrent affection. Autopsies are rare. With two exceptions the results of autopsies have been uniformly to show changes in muscular tissue, and no primary changes in the spinal cord or nerves. The changes in the muscles consist in an increase of interstitial tissue and fat among the muscular fibres, pressing them apart; a diminution in the size of the individual fibres, the striæ being retained, but becoming finer as the size of the fibres decrease; in extreme cases a diminution in the number of the fibres; no fatty degeneration of the fibres, as is seen in progressive muscular atrophy. Very rarely there have been found hypertrophied muscular fibres. These changes have been seen not only in fatal cases, but in others, when portions of the muscles have been removed by a harpoon.

In the cord, Brieger ${ }^{1}$ observed no change. N. H. Bay ${ }^{2}$ found a slight amount of sclerosis of the lateral columns, which was thought to be secondary. Cohnheim found no change in the cord. Charcot in two cases ${ }^{8}$ found no change in the cord. Gowers and Clarke 4 found granular degeneration around the blood-vessels, the nerve cells being entirely healthy. These changes Gowers ${ }^{5}$ thinks are secondary, and due to disturbances of the system which arise shortly before death.

Of the two exceptions above referred to, one is by Barth. ${ }^{6}$ The nerve cells of the anterior cornua were affected. This case was that of an adult, and the date at which it began, the course of the disease, the aggregation of symptoms, and the morbid changes all concur in raising a question as to its identity with the disease under consideration. The second is a case by Müller.7 There was a fall at four years of age. The account does not state when the weakness was noticed. There were club-feet; one leg was smaller than natural, the other larger. The patient, a girl, at the time of observation was insane, and remained so till death, the insanity being rather of the nature of general paralysis. It is impossible to distinguish whether the changes in the cord belonged to the muscular hypertrophy or to the general affection of the nervous system. The case was clearly complicated and exceptional.

The weight of evidence so far is opposed to the spinal origin of the disease; the only change which has been found constantly is muscular. Gowers ${ }^{8}$ suggests that the affection may be due to a congenital error of development, in consequence of which the muscles are affected at the time when the earliest strain is put upon them. ${ }^{9}$

The case reported so briefly in this journal for August 21st is not a typical case of the disease; every particular given differs from what is usually found. The case began at eleven years, much later than usual. There is complete paralysis of the legs after three years, which has not occurred so soon in cases beginning late in early childhood. The muscles of the thighs are affected. The calves are almost invariably the first to enlarge.

1 Archiv für klin. Med., 1878, page 200.

2 Hospitals Tiedende, 1877.

3 Arch. de Physiol., iv., 1871. Leçons sur les Maladies du Système nerveux, t. ii., 1877.

4 Med. Chir. Transactions, vol. lvii., page 247.

5 Lancet, July, 1879.

6 Arch. d. Heilkunde, xii., 1871, page 121.

7 Beiträge zur pathologische Anat. und Physiol. des mensch. Rückenmarks, 1871.

${ }^{8}$ Lancet, July, 1879.

9 If "Enquirer" can conveniently refer to the London Lancet for July, he will find the paper by W. R. Gowers well worth reading. 